\title{
Fiscaoeconomia
}

E-ISSN: 2564-7504

2021, Volume 5, Issue 3, 879-901

https://dergipark.org.tr/tr/pub/fsecon

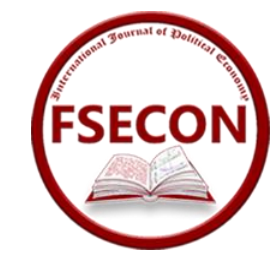

Research Article/Araştırma Makalesi

Submitted/Geliş: 30.05.2021

Accepted/Kabul: 07.09.2021

Doi: $10.25295 /$ fsecon.945256

\section{Demografik Göstergelerin Enflasyonla İlişkisi: Avrupa Birliği Örneği}

The Relationship Between Demographic Indicators and Inflation: The Example of the European Union

\section{Emin Ahmet KAPLAN ${ }^{1}$, Neslihan BURGAZ ${ }^{2}$}

\section{Öz}

$A B$ ülkelerinin "baby boom" sonrası kadın başına düşen çocuk sayısı hızla azalmış ve günümüzde bu sayı nüfusun yenilenme düzeyinin altında seyretmiştir. Kadın başına çocuk sayısının azalması nedeniyle genç bağımlı nüfus ve çalışma çağındaki nüfus yapısı da etkilenmiştir. Bu süre zarfında bilim, teknoloji ve sağlık sistemindeki gelişmeler neticesinde ölüm oranları azalmış ve yaşlı bağımlı nüfus artmıştır. Doğum ve ölüm oranlarındaki azalışın demografik göstergelere yansıması toplam talep ve toplam arz aracılığıyla enflasyonu etkilemektedir.

Bu kapsamda çalışmada AB ülkelerinde 1996-2020 dönemine ait demografik göstergelerin enflasyon üzerinde etkisini test etmek için panel veri analizi yapılmıştır. Bağımlı değişken olarak enflasyon, bağımsız değişken olarak ise demografik göstergeler, GSYH ve işsizlik kullanılmıştır. Analiz sonucuna göre yaşlı bağımlı nüfusun, ekonomik büyümenin, işsizliğin, çalışma çağındaki nüfusun enflasyonu düşürdüğü, genç bağımlı nüfusun ve nüfus artış hızındaki artışın ise enflasyonu yükselttiği tespit edilmiştir.

Jel Kodları: E31, N30, C33.

Anahtar Kelimeler: Demografik Değişim, Avrupa Birliği, Enflasyon, Panel Veri Analizi.

\section{Abstract}

After the "baby boom" of EU countries, the number of children per woman decreased rapidly and today this number is below the replacement level of the population. Due to the decrease in the number of children per woman, the structure of the young dependent population and the working age population has also been affected. During this period, as a result of developments in science, technology and health system, mortality rates decreased and the elderly dependent population increased. The reflection of the decrease in birth and death

\footnotetext{
${ }^{1}$ Dr., Karamanoğlu Mehmetbey Üniversitesi iißBF Ekonometri Bölümü, eminahmet@kmu.edu.tr ORCID: 0000-0002-4808-8529

${ }^{2}$ Dr., Karamanoğlu Mehmetbey Üniversitesi iïB Maliye Bölümü, neslihankaracam@kmu.edu.tr ORCID: 0000-0001-8301-2792
}

Citation/Atıf: Kaplan, E. A. \& Burgaz, N. (2021). Demografik Göstergelerin Enflasyonla Illişkisi: Avrupa Birliği Örneği. Fiscaoeconomia, 5(3), 878-901. Doi: 10.25295/fsecon.945256 
Kaplan, E. A. \& Burgaz, N. (2021). Demografik Göstergelerin Enflasyonla illişkisi: Avrupa Birliği Örneği. Fiscaoeconomia, 5(3), 879-901. Doi: 10.25295/fsecon.945256

rates on demographic indicators affects inflation through aggregate demand and aggregate supply.

In this context, panel data analysis was conducted to test the effect of demographic indicators for the period 1996-2020 on inflation in EU countries. Inflation was used as the dependent variable and demographic indicators, GDP and unemployment were used as the independent variables. According to the results of the analysis, it has been determined that the elderly dependent population, economic growth, unemployment, and the working age population reduce inflation, while the young dependent population and the increase in the population growth rate increase inflation.

Jel Codes: E31, N30, C33.

Keywords: Demographic Change, European Union, Inflation, Panel Data Analysis.

\section{Giriş}

Demografik göstergeler nüfus artış hızı, kaba doğum oranı, kaba ölüm oranı, toplam doğurganlık hızı, bebek ölüm oranı, çalışma çağındaki nüfus, genç bağımlı nüfus ve yaşlı bağımlı nüfus olarak sıralanmaktadır. Bu göstergeler temel demografik göstergeler arasında yer almaktadır. Doğum ve ölüm oranlarındaki artış veya azalışa bağlı olarak demografik göstergeler değişiklik göstermektedir.

Demografik göstergelerdeki değişimlerin sosyal, kültürel ve ekonomik etkileri bulunmaktadır. Bu göstergelerin sosyal unsurlar olması ve uzun vadede etkilerinin ortaya çıkması sebebiyle ekonomi alanında yapılan çalışmalar sınırlı düzeyde kalmıştır. Ekonomi alanında yapılan çalışmalarda ise demografik göstergelerin ekonomik büyüme ve tasarruf üzerindeki etkilerine yoğunlaşılmasına rağmen enflasyonla ilgili çalışmalar son yıllarda ilgi çekici hale gelmiştir.

Bu kapsamda çalışmada $A B$ ülkelerinin demografik göstergelerindeki değişiminin enflasyon üzerindeki etkisi incelenecektir. Çalışma üç bölümden oluşmaktadır. illk bölümde analizde kullanılacak olan demografik göstergelerin tanımı ve $A B$ ülkelerinde demografik göstergelerin seyri anlatılacaktır. İkinci bölümde enflasyonun tanımı, enflasyonla demografik göstergelerin ilişkisi ve $A B$ ülkelerinin enflasyon süreci aktarılacaktır. Üçüncü bölümde ise demografik göstergelerin enflasyon üzerine etkisi panel veri analizi ile test edilecek ve ardından sonuç ve değerlendirme bölümü ile çalışma tamamlanacaktır.

\section{Demografik Göstergeler}

\subsection{Demografik Göstergeler Kavramı}

Bir nüfusun belirli bir zaman dilimi boyunca büyümesi veya azalması doğumlar ve ölümler tarafından belirlenmektedir (United Nations, 1953: 47). Doğum ve ölüm oranlarındaki azalma veya artma demografik yapılarda bir dönüm noktası olmakta ve nüfus artış hızı, bağımlı nüfus ve çalışma çağındaki nüfus üzerinde etkisi bulunmaktadır (Yoon ve ark., 2014:5).

Nüfus artış hızı demografik göstergelerin en temel unsuru olarak yer almaktadır. Nüfus bileşenleri olan doğum ve ölüm oranı ile ilgili en önemli demografik ölçüm olarak kabul edilmektedir. Nüfus artış hızı, açık bir şekilde ekonomik düzey veya ekonomik değişimin bir 
Kaplan, E. A. \& Burgaz, N. (2021). Demografik Göstergelerin Enflasyonla illişkisi: Avrupa Birliği Örneği. Fiscaoeconomia, 5(3), 879-901. Doi: 10.25295/fsecon.945256

göstergesi olmasa da mevcut olabilecek herhangi bir ekonomik faaliyetin doğrudan ölçümünü ilişkilendirmek için temel bir veri olarak yer almaktadır (Hauser, 1959:100-106).

Demografik gösterge olarak yer alan ikinci unsur bağımlı nüfustur. Bağımlı nüfus çalışamayacak kadar genç veya yaşlı olan ve genellikle 20 yaş altı veya 65 yaş üstü nüfus olarak tanımlanmaktadır (Kleiman, 1967:876). Nüfus yaş yapılarına göre değerlendirildiğinde 0-14 yaş aralığı olarak adlandırılan nüfus genç bağımlı nüfus ve 65 yaş üstü nüfus ise yaşlı bağımlı nüfus olmak üzere ikiye ayrılmaktadır (Günaydın, 2018:5). Bağımlı nüfus, çalışma çağındaki nüfusun taşıması gereken yükün bir ölçüsünü göstermektedir. Bu yük, çocuklardan, gençlerden ve emeklilik yaşındaki insanlardan oluşmaktadır. Dolaylı olarak bu yaş gruplarındaki kişilerin üretime katılmadıkları ve nüfusun geri kalanı tarafından bakıldıkları varsayılmaktadır (Kleiman, 1967:877).

Demografik göstergeler olarak yer alan son unsur ise çalışma çağındaki nüfustur. OECD tarafından yapılan tanıma göre çalışma çağındaki nüfus 15-64 yaşları arasındaki nüfus olarak tanımlanmaktadır. Bu gösterge, çalışma çağındaki nüfusun toplam nüfus içindeki payını ölçmektedir (OECD). Çalışma çağındaki nüfusun görece büyüklüğü bağımlı nüfusa destek sağlama açısından önemlidir. Bu nüfusun büyüklüğü ne kadar yüksek olursa bağımlı nüfusun ekonomik yükünü kaldırma potansiyeli de o kadar artmaktadır. Ancak çalışma çağındaki nüfusun büyüklüğü farklı nedenlerle de olsa hem gelişmiş hem de gelişmekte olan ülkeler için bir endişe kaynağı olmaktadır. Gelişmiş ülkeler genellikle çalışma çağındaki nüfusunun çok küçük olması veya yavaş büyümesi nedeniyle endişelenmektedir. Gelişmiş ülkeler karşılanmamış kısa vadeli işgücü taleplerini karşılamak için genellikle geçici nitelikte olan uluslararası göçü kabul etmek zorunda kalmaktadır. Bunun aksine, gelişmekte olan ülkeler ise tipik olarak büyük ve hızla büyüyen işgücü nedeniyle herkes için insana yakışır istihdam sağlama zorluğundan endişe duymaktadır (United Nations, 2011:17). Dolayısıyla yaş endeksinin (15-64 yaş arası nüfusun toplam nüfus içindeki payının) değişkenliği ile ilişkili olarak; yerel ve iktisadi koşullarda meydana gelen dalgalanmalar nedeniyle aktif nüfusun artmasına rağmen istihdam olanaklarının artmaması, gelecekteki iş olanaklarının daralma ihtimali ve mevsimsel ya da konjonktürel işsizlik olgusu ülkeler arasındaki farklılıklar açısından önem taşımaktadır (Dayıoğlu, 2018: 214).

\subsection{Avrupa Birliği Ülkelerinin Demografik Göstergeleri}

Nüfusun yaş dağılımındaki değişiklikler $A B$ ülkelerinde son elli yılda belirginleşmiştir. İkinci Dünya Savaşı sonrası dönemdeki "baby boom" sonrası $A B$ ülkelerinde bu değişim süreci başlamıştır (Prskawetz ve ark., 2007:5). "Baby boom" genellikle dünyanın gelişmiş ülkelerinde özellikle de II. Dünya Savaşı'na katılan ülkelerin çoğunda, 1940'ların ortasından 1960'ların sonlarına kadar meydana gelen bir demografik canlanma dönemi olarak görülmektedir (Akyıldız, 2020:5653). Evlilik oranlarının hızlanması ve toplam doğurganlığın artması bu dönemde nüfus dinamiklerini değiştirmiştir. 1960'lardan günümüze $A B$ ülkelerinde toplam doğurganlık oranları keskin bir şekilde düşmüştür (Bavel ve Reher, 2013:257).

AB ülkelerinde 1960 'da kadın başına canlı doğan çocuk sayısı 2.6 düzeyindeyken, 1980 yılından sonra bu sayı iki çocuğun altına düşmüştür. 1990 yılında kadın başına canlı doğan çocuk sayısı 1.77 iken 1996 yılında 1.5 altına düşmüş, 2006 yılından sonra ise 1.54 çocuk sayısında sabit kalmıştır (Dünya Bankası). Bu azalışın arkasında kadınların eğitim imkânın artması, ekonomik özerkliğini sağlaması, hanelerde ikinci bir gelire ihtiyaç duyulması, kadınların işgücüne 
Kaplan, E. A. \& Burgaz, N. (2021). Demografik Göstergelerin Enflasyonla iliş̧kisi: Avrupa Birliği Örneği. Fiscaoeconomia, 5(3), 879-901. Doi: 10.25295/fsecon.945256

katılımının artmasını teşvik edici yüksek tüketim istekleri, işyerinde artan rekabetle birlikte her iki cinsiyette de kariyer gelişimine yapılan yatırımların artması, kendini gerçekleştirme ve rahat bir gelecek arzusudur (Akt. Jozwiak ve Kotowska, 2008:231).

$A B$ ülkelerinde doğum oranlarının azalmasıyla birlikte genç bağımlı nüfus ve çalışma çağındaki nüfus oranları da azalmıştır. Bu azalma uzun vadeli olarak demografik göstergelere yansıması sebebiyle bu çerçevede değerlendirmek gerekmektedir. Aşağıdaki Grafik 1'de AB ülkelerinde genç bağımlı nüfus, yaşı bağımlı nüfus ve çalışma çağındaki nüfus oranlar yer almaktadır.

Grafik 1: AB Ülkelerinde Demografik Göstergeler

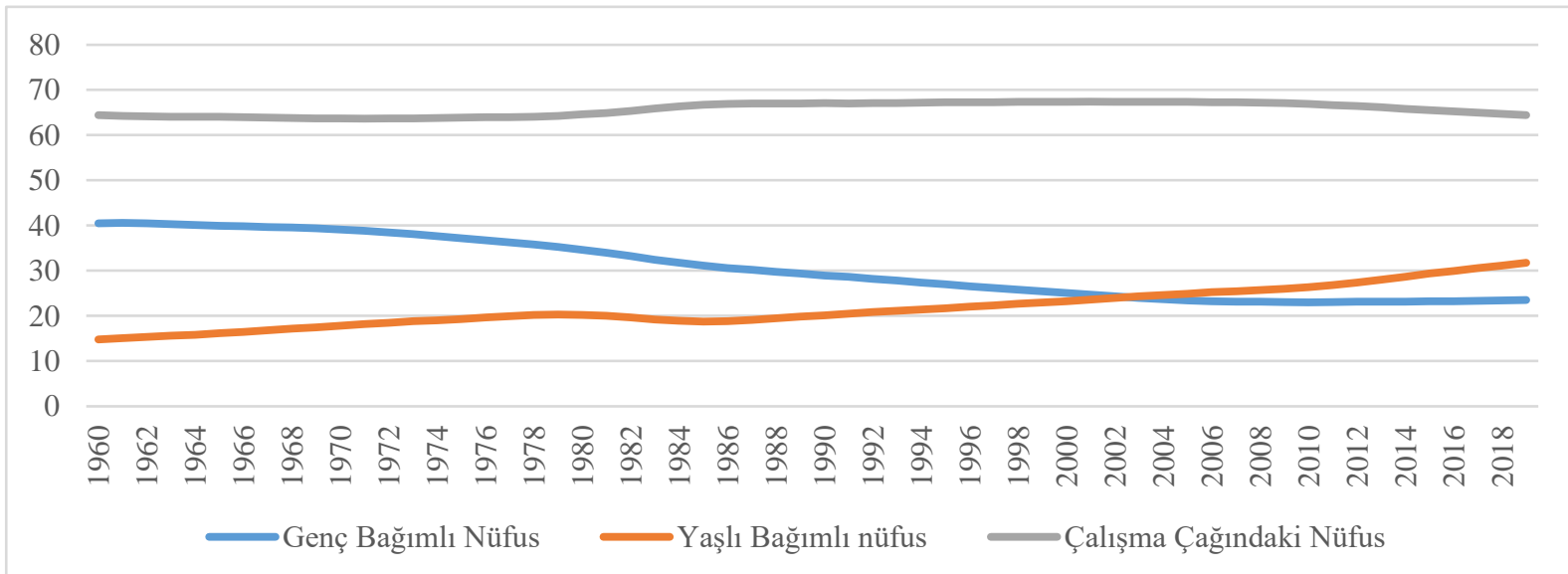

Kaynak: Dünya Bankası

1960 yılında $A B$ nüfusunun \%40'ı genç bağımlı nüfustan oluşmaktayken doğum oranlarının azalması ile birlikte 2019 yılında bu oran yaklaşık \%23 düzeyine düşmüştür. Çalışma çağındaki nüfus ise 1960 yılında \%64 düzeyindeyken 1990'lı yılların başında \%68 düzeyine yükselmiş ve 2010 yılından sonra bu oran düşüşe geçmesiyle 2019 yılında \%66 düzeyine düşmüştür (Dünya Bankası).

AB ülkelerinde yaşlı bağımlı nüfus 1960'larda \%11 düzeyindeyken 1995 yılında bu oran \%22'ye, 2020 yılında ise \%31 düzeyine ulaşmıştır. Bu artışın arkasında yatan temel neden doğurganlık oranlarındaki uzun vadeli düşüş ve artan yaşam beklentisidir (Karatağ ve Akyıldız, 2019:581). Bu artışa çocuk ölümlerinde azalma, halk sağlığı ve tıbbi teknolojilerdeki gelişmeler, sağlıklı bir yaşam tarzına artan farkındalık, ağır iş gücünden üçüncül mesleklere doğru bir geçiş ve iyileştirilmiş yaşam koşulları dâhil olmak üzere bir dizi farklı faktör etkili olmuştur (European Commission, 2012:8).

Nüfus projeksiyon tahminlerine göre $A B$ ülkelerinde 2100 yılına kadar demografik göstergelerde yaşanan değişimin devam edeceği tahmin edilmektedir. 2030-2100 yılı arasında yaşlıların toplam nüfus içindeki payının daha da artacağı, genç bağımlı nüfus ve çalışma çağındaki nüfusun azalmaya devam edeceği öngörülmektedir. Aşağıdaki Grafik 2'de AB ülkelerinin nüfus projeksiyon tahminlerine göre demografik göstergeler yer almaktadır. 
Kaplan, E. A. \& Burgaz, N. (2021). Demografik Göstergelerin Enflasyonla İlişkisi: Avrupa Birliği Örneği.

Fiscaoeconomia, 5(3), 879-901. Doi: 10.25295/fsecon.945256

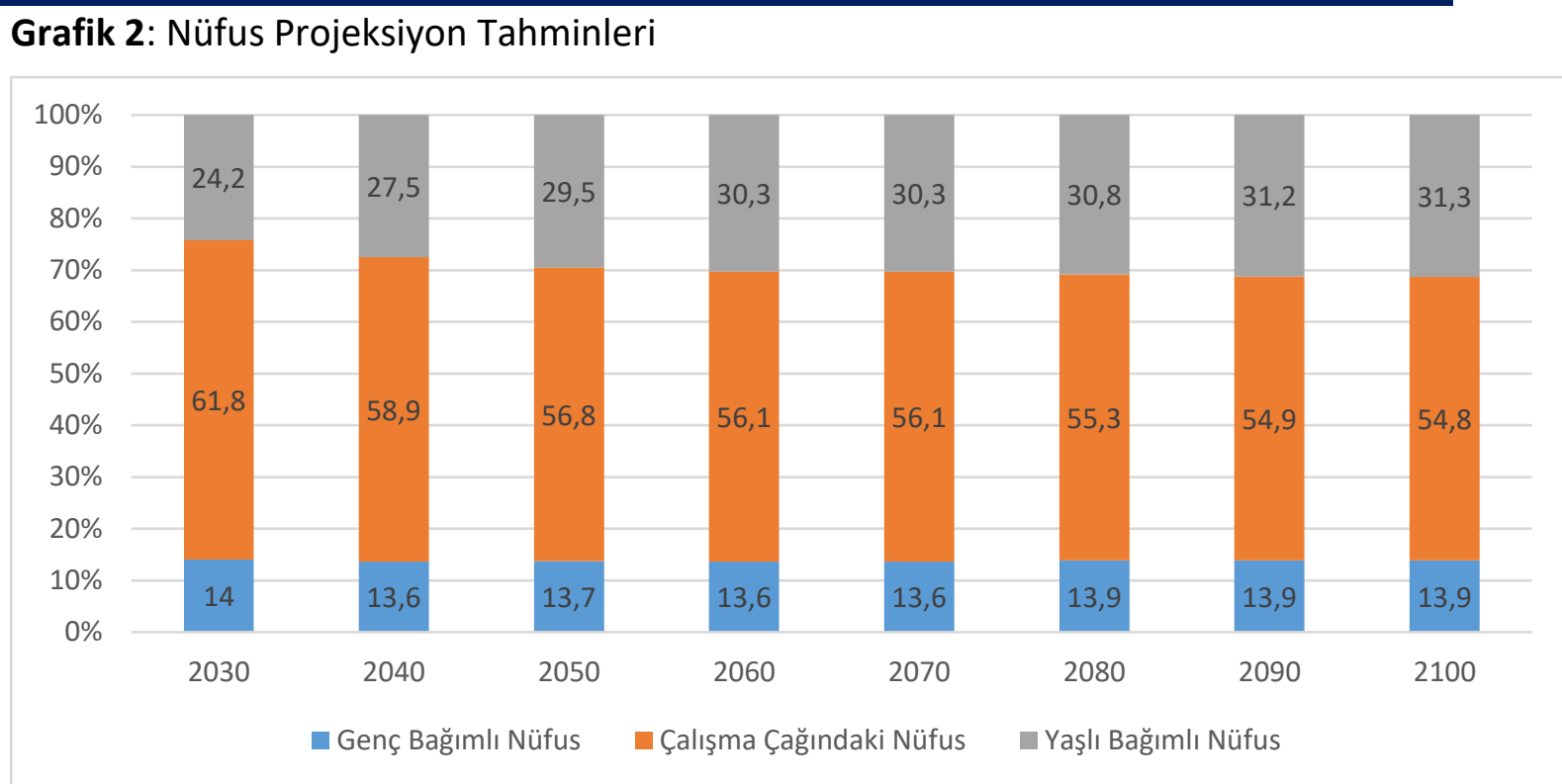

(Eurostat, 2020:8)

\section{Enflasyon Kavramı}

\subsection{Enflasyon Tanımı}

Enflasyon fiyatlar genel seviyesinin belirli bir dönemde sürekli olarak artması olarak tanımlanmaktadır. Enflasyonun nedeni toplam talep ve maliyet artışından kaynaklanmaktadır. Toplam talep fazlalığı olarak ifade edilen ayrımda cari fiyatlarla toplam mal ve hizmet arzının toplam talepten az olmasından kaynaklanmaktadır (Ataç, 2009:162-163). Maliyet artışı ise toplam talepte herhangi bir artış olmamasına rağmen mal ve hizmetlerin üretiminde kullanılan girdilerin maliyetlerinin artma durumudur. Hammadde, enerji fiyatları ve ücretlerin artışının maliyetlere yansıması sonucunda fiyatlar genel seviyesinin artmasıdır (Birinci, 1989:21).

Demografik göstergeler enflasyonu toplam talep ve maliyet aracılığıyla etkilemektedir. Nüfus artış hızı arttığında toplam talep artmakta ve enflasyon üzerinde pozitif etkisi bulunmaktadır. Bunun nedeni, kısa veya orta vadede demografik şoklara tepki olarak toplam arz ayarlamasının toplam talep ayarlamasından daha yavaş olmasından kaynaklanmaktadır (Yoon ve ark., 2014:19). Yaşlı bağımlı nüfusun artışı ise enflasyonu hem arz hem de talep kanallarından etkileyebilmektedir. Talep tarafından bakıldığında düşük gelirli yaşı bağımlı nüfusun artışı toplam tüketimi sınırlamasına rağmen yaşlı bağımlı nüfusun daha fazla tüketme eğilimi ise toplam tüketimi artırmakta ve enflasyon yükselmektedir. Arz tarafında ise işgücü arzının azalması sebebiyle artan ortalama ücretler enflasyonun yükselmesine neden olmaktadır (Yoon ve ark., 2014:11).

Genç bağımlı nüfus ve çalışma çağındaki nüfus ise enflasyonu toplam talep üzerinden etkilemektedir. Genç bağımlı nüfusun gelirleri az olduğu, çalışma çağında bu gelirlerin yükseldiği ve yaşlıııta ise düştüğü göz önüne alındığında çalışma çağındaki nüfus genç ve yaşlı bağımlı nüfusa kıyasla gelirlerinden daha fazla tasarruf sağlanmaktadır. Emekli olduklarında birikmiş birikimleriyle tüketimlerini finanse etmektedirler. Bu bakımdan çalışma çağındaki nüfusun tasarruf eğilimlerinin yüksek olması sebebiyle toplam talebin azalması sonucu 
Kaplan, E. A. \& Burgaz, N. (2021). Demografik Göstergelerin Enflasyonla illişkisi: Avrupa Birliği Örneği. Fiscaoeconomia, 5(3), 879-901. Doi: 10.25295/fsecon.945256

enflasyonun düşmesine neden olmaktadır. Genç bağımlı nüfus ise toplam tasarruf oranlarının az olması sebebiyle toplam tüketimi artırmakta ve enflasyon üzerinde etkisi pozitif olmaktadır (Bobeica ve ark., 2006:5).

\subsection{Avrupa Birliği Ülkelerinde Enflasyon}

II. Dünya Savaşı'ndan kısa bir süre sonra Avrupa'da kalıcı barışı sağlamaya yardımcı olacağı fikriyle başlayan Avrupa entegrasyon süreci kömür ve çelik endüstrilerinin tek bir uluslar üstü otorite altında koordine edilmesi amacıyla 1952'de Belçika, İtalya, Lüksemburg ve Hollanda'nın katılımıyla Avrupa Çelik ve Kömür Topluluğu kurulmasını sağlamıştır. Bu topluluğun başarısına dayanarak Avrupa Ekonomik Topluluğu ve Avrupa Atom Enerjisi Topluluğu 1957'de Roma Antlaşması ile kurulmuştur (Duarte, 2003:54-55). Topluluk ilk başta ekonomik kriterlerden bağımsız olarak kurulmasına rağmen zamanla ekonomik amaçlı bir birlikteliğe doğru dönmüştür (Kocağ ve Bakan, 2013:943).

Topluluğun 1968'de yılına gelindiği zaman ortak gümrük tarifesini yürürlüğe koyarak “Ortak Pazarı" tesis etmişlerdir. 1969 yılında ise üye ülkeler Avrupa Ekonomi ve Para Birliği kurulmasına karar vermişlerdir (Nişancı ve ark., 2014: 1-2). 1970 yılında topluluğun bütçesi kendi kaynaklarından oluşmasının kararı alınarak Lüksemburg Antlaşması imzalanmıştır. 1973 ve 1982 yılında yaşanan petrol şokları sebebiyle ortaya çıkan kriz koşullarını düzeltmek için Avrupa Birliği'nde yeni bir süreci başlatarak Tek Avrupa Senedi imzalanmış ve 1987 yılında yürürlüğe girmiştir (Akçay ve ark., 2011:121-122).

Üye ülkeler arasında ekonomik koşullar arasındaki farlıı̆̆ı kapatmak amacıyla 1992 yılında Maastricht kriterleri kabul edilmiştir. AB ülkelerinin titizlikle ele aldığı konulardan biri ekonomik istikrardır ve Maastricht kriterleri de bu istikrarın belirleyici unsuru olmuştur (Kocağ ve Bakan, 2013:943). Maastricht kriterleri dört ana kriterden oluşmaktadır. Bu kriterler; "Toplulukta en düşük enflasyona sahip (en iyi performans gösteren) üç ülkenin yıllık enflasyon oranları ortalaması ile ilgili üye ülke enflasyon oranı arasındaki fark 1.5 puanı geçmemelidir. Üye ülke devlet borçlarının GSYH'ye oranı \%60'ı geçmemelidir. Üye ülke bütçe açığının GSYH'ye oranı \%3'ü geçmemelidir. Herhangi bir üye ülkede uygulanan uzun vadeli faiz oranları 12 aylık dönem itibariyle, fiyat istikrarı alanında en iyi performans gösteren 3 ülkenin faiz oranını 2 puandan fazla aşmayacaktır." olarak sıralanmaktadır.

Maastricht kriterleri kararı öncesinde $A B$ ülkelerinde çarpık işgücü piyasaları, enflasyonu yükselten vergi sistemleri ve diğer yapısal engellerin tetiklediği tutarsız politikalar nedeniyle Avrupa'da düşük enflasyonlu bir ortam sağlanması zorlaşmıştır. Bu nedenle $A B$ ülkelerinin ortak para birimine geçmek için temel ekonomik reformlar yapmaya teşvik etmek amacıyla Maastricht enflasyon kriteri gibi çeşitli giriş kriterleri koyulmuştur (Bulir ve Hurnik, 2006: 4).

Maastricht Kriterleri 1990'ların başında İtalya gibi "yüksek enflasyonlu" ülkelerin Almanya ve Hollanda gibi "düşük enflasyonlu" ülkelerle aynı çizgide getirmek için tasarlanmıştır (Bulir ve Hurnik, 2006: 3).

AB ülkelerinde yaşanan bu gelişmeler sayesinde 1990'lı yıllarda en düşük seviyede gerçekleşmiştir. Maastricht kriteri ile alınan kararlar ve tek bir para birimine geçmek isteyen ülkelerin mali disiplin ve fiyat istikrarı sağlamada başarılı olması sayesinde enflasyon düşüşü sağlanmıştır (Eraslan, 2011:68). 
Kaplan, E. A. \& Burgaz, N. (2021). Demografik Göstergelerin Enflasyonla illişkisi: Avrupa Birliği Örneği. Fiscaoeconomia, 5(3), 879-901. Doi: 10.25295/fsecon.945256

AB ülkeleri fiyat istikrarını sağlamak amacıyla bu süreci daha da ileri götürerek ortak para birimi olan Euro'ya geçiş süreci başlatmıştır. Parasal birliğe giden süreç Avrupa Merkez Bankası (ECB) kurulmasıyla başlamıştır. ECB'nin görevi, üye ülkeler arasında para politikalarının koordinasyonunu güçlendirmek, tek bir para politikası ve para birimi için gerekli hazırlıkları yapmaktır. Üye ülkeler parasal bağımsızlıklarını terk etmişler ve para politikası ECB'nin kontrolüne geçmiştir (Duarte, 2003:55).

1999 'da enflasyonist baskıların yokluğu $A B$ ekonomisinin yüksek derecede fiyat istikrarını sürdürmesine izin vermiştir. Enflasyon oranı 1999'da \%1'e düşmüştür. İç talep ve üretim koşullarının iyileşmesi de $A B^{\prime}$ de enflasyon oranının düşmesine katkıda bulunmuştur. 1999 yılından günümüze $A B$ ülkelerinde düşük enflasyon devam etmiştir (Papaioannou, 2004:9).

$A B$ ülkelerinde enflasyonu düşük seviyede olmasını sağlayan itici güç enerji ve hammadde fiyatlarının etkisidir. 2008 Krizinin ardından petrol fiyatlarının beklenmedik çöküşüyle enflasyon hızla düşmüştür. 2010 yılında petrol fiyatları kriz öncesi seviyelerine dönmüş ve genel olarak 2010'ların ilk yarısında krize bağlı şoklara rağmen ortak para birimi projesi başarılı olmuştur (Akt. DeNederlandscheBank, 2016:29). Euro'nun ilk yirmi yıllık işleyişi, istikrarını, ikinci en önemli küresel para birimi olma rolünü ve ECB enflasyonu düşük tutma yeteneğini doğrulamıştır (Dabrowski, 2019:7). Petrol fiyatları 2014'ten itibaren yeniden çok düşük seviyelere düşerken, enflasyon da düşmüştür (Akt. DeNederlandscheBank, 2016:29). Enflasyon, 2013'ün başından bu yana istikrarlı bir şekilde düşmüş hatta 2014'ün sonlarında negatife dönmüştür. Düşüşün bir kısmı petrol fiyatlarından kaynaklansa da toplam talebin zayıflığı da önemli bir rol oynamaktadır.

Euro bölgesindeki düşük enflasyon oranları hem arz hem de talep yönlü faktörlerin bir araya gelmesinin sonucudur. Enerji ve gıda fiyatlarındaki yavaşlama dâhil olmak üzere küresel arz yönlü faktörler en önemli rolü oynamıştır. Euro efektif döviz kurundaki değerlenme, emtia fiyatlarının etkisini artırarak enflasyondaki düşüşe de katkıda bulunmuştur. İşgücü ve ürün piyasalarındaki yapısal reformların etkisi gibi yerel faktörler de fiyat baskılarının zayıflamasına katkıda bulunmuştur. Aynı zamanda, özellikle kriz öncesi aşırılıkların hala gevşemekte olduğu ülkelerde, talep yönlü faktörler enflasyon üzerinde baskı oluşturmuştur (European Central Bank, 2014:68).

\section{Literatür taraması}

Literatürde enflasyon üzerine yapılan çalışmalarda enflasyonun nedenleri ve sonuçları üzerine oldukça fazla çalışma bulunmaktadır. Bu çalışmaların hemen hepsi ekonomik açıdan incelenmiş ve sosyal göstergeler ile ilişkisi sınırlı düzeyde kalmıştır. Son zamanlarda demografik değişkenlerin enflasyon üzerine etkisine dair akademik çalışmalar sınırlı düzeyde de olsa yapılmaktadır. Demografik göstergelerin seyrinin uzun vadeli döneme yayılması çalışmaların sınırlı düzeyde kalmasının en önemli nedenleri arasında yer almaktadır.

Demografik göstergelerin enflasyon üzerine yapılan çalışmalarda özellikle gelişmiş ülkelerde yaşlı bağımlı nüfus ve çalışma çağındaki nüfus artışının enflasyon üzerinde etkisinin negatif yönlü olduğu, nüfus artış hızının ve genç bağımlı nüfusun ise enflasyon üzerinde pozitif yönde etkilediği tespit edilmiştir. Aşağıdaki Tablo 1'de demografik göstergelerin enflasyon üzerine etkisine dair yapılan çalışmalara ilişkin özet bilgiler yer almaktadır. 
Kaplan, E. A. \& Burgaz, N. (2021). Demografik Göstergelerin Enflasyonla İlişkisi: Avrupa Birliği Örneği. Fiscaoeconomia, 5(3), 879-901. Doi: 10.25295/fsecon.945256

Tablo 1. Literatür Taraması

\begin{tabular}{|c|c|c|c|c|c|}
\hline Yazar & Ülke & $\begin{array}{l}\text { Bağımlı } \\
\text { Değişken }\end{array}$ & $\begin{array}{l}\text { Bağımsız } \\
\text { Değişken }\end{array}$ & Yöntem & Sonuç \\
\hline $\begin{array}{l}\text { Han } \\
(2019)\end{array}$ & $\begin{array}{l}\text { Hong Kong- } \\
\text { Çin-Singapur } \\
(1991-2016)\end{array}$ & Enflasyon & $\begin{array}{l}\text { Genç ve yaşlı } \\
\text { bağımlı } \\
\text { nüfus, GSYH, } \\
\text { reel faiz oranı }\end{array}$ & $\begin{array}{l}\text { GLS } \\
\text { Panel VAR }\end{array}$ & $\begin{array}{l}\text { Genç bağımlılığı ile } \\
\text { enflasyon arasında ilişki } \\
\text { pozitif, yaşlı bağımlılığı } \\
\text { enflasyon arasında ilişki } \\
\text { negatif }\end{array}$ \\
\hline $\begin{array}{l}\text { Vlandas } \\
(2016)\end{array}$ & $\begin{array}{l}21 \text { OECD Ülke } \\
(1960-2012)\end{array}$ & Enflasyon & $\begin{array}{l}\text { Yaşlı bağımlı } \\
\text { nüfus }\end{array}$ & $\begin{array}{l}\text { Panel veri } \\
\text { analizi }\end{array}$ & $\begin{array}{l}\text { Yaşlı bağımlı nüfus } \\
\text { enflasyon arasında negatif } \\
\text { yönlü ilişki }\end{array}$ \\
\hline $\begin{array}{l}\text { Bobeica } \\
\text { ve ark. } \\
(2017)\end{array}$ & $\begin{array}{l}\text { Euro bölgesi, } \\
\text { ABD ve } \\
\text { Almanya } \\
(1975-2016)\end{array}$ & Enflasyon & $\begin{array}{l}\text { Demografik } \\
\text { göstergeler }\end{array}$ & $\begin{array}{l}\text { Eş } \\
\text { bütünleşik } \\
\text { VAR analizi }\end{array}$ & $\begin{array}{l}\text { Euro bölgesinde çalışma } \\
\text { çağındaki nüfus ve nüfus } \\
\text { artış hızı enflasyonla } \\
\text { arasında pozitif ilişkili } \\
\text { Amerika ve Almanya'da } \\
\text { ise negatif ilişki olduğu } \\
\text { tespit edilmiştir. }\end{array}$ \\
\hline $\begin{array}{l}\text { Juselius } \\
\text { ve Takats } \\
\text { (2015) }\end{array}$ & $\begin{array}{l}22 \text { Ülke } \\
\text { (1955-2010) }\end{array}$ & Enflasyon & $\begin{array}{l}\text { Demografik } \\
\text { değişkenler }\end{array}$ & $\begin{array}{l}\text { Panel veri } \\
\text { analizi }\end{array}$ & $\begin{array}{l}\text { Bağımlı ve çalışma } \\
\text { çağındaki nüfus enflasyon } \\
\text { üzerinde pozitif ilişki } \\
\text { tespit edilmiştir. }\end{array}$ \\
\hline $\begin{array}{l}\text { Broniato } \\
\text { wska } \\
\text { (2019) }\end{array}$ & $\begin{array}{l}32 \text { OECD Ülkesi } \\
(1971-2015)\end{array}$ & Enflas & $\begin{array}{l}\text { Yaşlı bağımlı } \\
\text { nüfus, genç } \\
\text { bağımlı } \\
\text { nüfus, } \\
\text { çalışma } \\
\text { çağındaki } \\
\text { nüfus }\end{array}$ & $\begin{array}{l}\text { Panel Veri } \\
\text { Analizi }\end{array}$ & $\begin{array}{l}\text { Yaşlı bağımlı nüfus } \\
\text { enflasyon arasında negatif } \\
\text { yönlü ilişki genç bağımlı ve } \\
\text { çalışma çağındaki nüfus } \\
\text { enflasyonla pozitif yönlü } \\
\text { ilişki olduğu tespit } \\
\text { edilmiştir. }\end{array}$ \\
\hline $\begin{array}{l}\text { Jaffrı ve } \\
\text { ark. } \\
(2016)\end{array}$ & $\begin{array}{l}\text { Pakistan } \\
(1988-2014)\end{array}$ & Enfla & $\begin{array}{l}\text { Nüfus artış } \\
\text { hızı ve } \\
\text { çalışma } \\
\text { çağındaki } \\
\text { nüfus }\end{array}$ & $\begin{array}{l}\text { ARDL } \\
\text { Yöntemi }\end{array}$ & $\begin{array}{l}\text { Nüfusun artışı ile } \\
\text { enflasyon arasında pozitif } \\
\text { ilişki, çalışma çağındaki } \\
\text { nüfus ile enflasyon } \\
\text { arasında ise negatif ilişki } \\
\text { tespit edilmiştir. }\end{array}$ \\
\hline $\begin{array}{l}\text { Andrews } \\
\text { vd. (2018) }\end{array}$ & $\begin{array}{l}22 \text { OECD Ülke } \\
(1990-2010)\end{array}$ & Enflasyon & 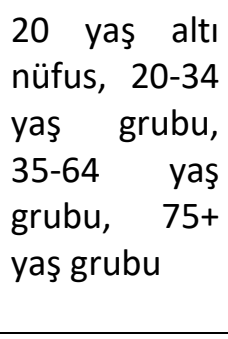 & $\begin{array}{l}\text { Panel eş } \\
\text { bütünleşm } \\
\text { e }\end{array}$ & $\begin{array}{l}\text { Genç bağımlı nüfus } \\
\text { enflasyonla arasında } \\
\text { pozitif ilişki, çalışma } \\
\text { çağındaki nüfus ve yaşlı } \\
\text { bağımlı nüfus enflasyonla } \\
\text { arasında negatif ilişki } \\
\text { bulunmaktadır. }\end{array}$ \\
\hline $\begin{array}{l}\text { Yoon ve } \\
\text { ark. }\end{array}$ & 30 OECD ülkesi & Enfla & $\begin{array}{l}\text { Demografik } \\
\text { göstergeler, }\end{array}$ & $\begin{array}{l}\text { Panel Veri } \\
\text { analizi }\end{array}$ & $\begin{array}{ll}\text { Nüfus artış hızı ve yaşlı } & \text { nüfusun } \\
\text { bağımlı } & \end{array}$ \\
\hline
\end{tabular}


Kaplan, E. A. \& Burgaz, N. (2021). Demografik Göstergelerin Enflasyonla İlişkisi: Avrupa Birliği Örneği. Fiscaoeconomia, 5(3), 879-901. Doi: 10.25295/fsecon.945256

\begin{tabular}{|c|c|c|c|c|c|}
\hline (2014) & $(1960-2013)$ & & $\begin{array}{l}\text { kişi başına } \\
\text { düşen GSYiH, } \\
\text { tasarruflar } \\
\text { /GSYiH, } \\
\text { yatırım / } \\
\text { GSYiH, bütçe } \\
\text { açığı / GSYiH }\end{array}$ & & $\begin{array}{l}\text { enflasyonu arttırdığı } \\
\text { tespit edilmiştir. }\end{array}$ \\
\hline $\begin{array}{l}\text { Manga ve } \\
\text { Cengiz } \\
(2020)\end{array}$ & $\begin{array}{l}\text { Türkiye (1980- } \\
\text { 2017) }\end{array}$ & Enflasyon & $\begin{array}{l}\text { Nüfus yaş } \\
\text { yapısı }\end{array}$ & $\begin{array}{l}\text { Bootstrap } \\
\text { Rolling } \\
\text { Window } \\
\text { nedensellik } \\
\text { testi } \\
\end{array}$ & $\begin{array}{lr}\text { Bağımlı genç } & \text { nüfus } \\
\text { enflasyonu } & \text { pozitif } \\
\text { etkilerken, Bağımlı yaşlı lı } & \text { nüfus ise negatif } \\
\text { etkilemektedir. } & \\
\end{array}$ \\
\hline $\begin{array}{l}\text { Liu ve } \\
\text { Westelius } \\
(2016)\end{array}$ & $\begin{array}{l}\text { Japonya } \\
(1990-2007)\end{array}$ & Enflasyon & $\begin{array}{l}\text { Demografik } \\
\text { göstergeler }\end{array}$ & $\begin{array}{l}\text { Arellano- } \\
\text { Bond GMM } \\
\text { tahmincisi }\end{array}$ & $\begin{array}{l}\text { Bağımlı yaşlı nüfus } \\
\text { enflasyon arasında negatif } \\
\text { ilişki, nüfus artış hızı ve } \\
\text { enflasyon arasında pozitif } \\
\text { ilişki tespit edilmiştir. }\end{array}$ \\
\hline
\end{tabular}

\section{Analiz}

\subsection{Veri, Yöntem ve Ampirik Bulgular}

\subsubsection{Veri}

Enflasyon ile demografik değişkenler ve makroekonomik değişkenler arasındaki ilişkiyi incelemek amacıyla 1996-2020 dönemi için 27 Avrupa Birliği üyesi ülke dikkate alınarak bir panel veri seti oluşturulmuştur. Bu çerçevede analiz, enflasyonun demografik değişkenler ve makroekonomik değişkenler açısından performans ölçümlerinin her biri üzerindeki etkisine odaklanmaktadır. Bu nedenle bağımlı değişken enflasyon oranı, bağımsız değişkenler ise yaşlı bağımlı nüfus, genç bağımlı nüfus, nüfus, çalışma çağındaki nüfus, nüfus artış hızı, GSYıH'daki reel büyüme ve işsizlik oranı olarak fonksiyon ilişkisi dikkate alınacaktır.

Broniatowska (2019) çalışmasından hareketle, ampirik modele ilişkin ilgili fonksiyon ilişkisi aşağıdaki gibidir:

$$
\text { Inf }=f(\text { Old, Young, Ccn, Gpop, Gdp, Unemp) }
$$

$\mathrm{Bu}$ çerçevede en genel haliyle aşağıdaki enflasyon modeli, ekonomik ve demografik değişkenler dikkate alınarak tahmin edilecektir:

$$
\operatorname{Inf}_{i t}=\beta_{0}+\beta_{1} \text { old }_{i t}+\beta_{2} \text { Young }_{i t}+\beta_{3} \text { Ccn }_{i t}+\beta_{4} \text { Gpop }_{i t}+\beta_{5} G d p_{i t}+\beta_{6} \text { Unemp }_{i t}+\varepsilon_{i t}(2)
$$

Bu modelde Inf enflasyon oranını, Old yaşı bağımlı nüfus oranını, Young genç bağımlı nüfus oranını, Ccn çalışma çağındaki nüfus hızını, Gpop nüfus artış hızını, Gdp reel GSYï büyüme oranını ve Unemp işsizlik oranını ifade etmektedir. $i$ analiz için modelde yer alan Avrupa 
Kaplan, E. A. \& Burgaz, N. (2021). Demografik Göstergelerin Enflasyonla İlişkisi: Avrupa Birliği Örneği. Fiscaoeconomia, 5(3), 879-901. Doi: 10.25295/fsecon.945256

Birliği'ne üye olan ülkeleri ${ }^{3}, t$ ise 1996-2020 olmak üzere yıllık zaman boyutunu ifade etmektedir. Iktisadi olarak beklentilerimiz yaşı bağımlı nüfus, genç bağımlı nüfus, nüfus artış hızı ve ekonomik büyümedeki pozitif artışın enflasyonu arttırması, çalışma çağındaki nüfus ve işsizlikteki pozitif artışın ise enflasyonu düşürmesi yönündedir. Tüm değişkenlere ilişkin veriler IMF ve World Bank veri tabanından elde edilmiştir. Değişkenlerin logaritması alınarak çift logaritmik model oluşturulmuştur.

Tablo 2, verilerin nasıl dağıldığını göstermek amacıyla modelde yer alan değişkenlerin tanımlayıcı istatistiklerinin bir özetini göstermektedir.

Tablo 2. Tanımlayıcı İstatistiklerin Özeti (1996-2020, Ülke Sayısı N=27)

\begin{tabular}{|c|c|c|c|c|c|}
\hline & Ortala. & Maks. & Min. & Std. Sap. & Gözlem \\
\hline LINF & 0.72 & 6.31 & -2.30 & 0.92 & 675 \\
\hline LOLD & 3.24 & 3.69 & 2.72 & 0.22 & 675 \\
\hline LYOUNG & 3.19 & 3.61 & 2.95 & 0.13 & 675 \\
\hline LCCN & 4.19 & 4.28 & 3.72 & 0.08 & 675 \\
\hline LGPOP & 0.17 & 3.65 & -3.85 & 0.76 & 675 \\
\hline LGDP & 1.06 & 3.23 & -2.30 & 0.71 & 675 \\
\hline LUNEMP & 2.04 & 3.31 & 0.69 & 0.47 & 675 \\
\hline
\end{tabular}

Panel veri setinde yer alan değişkenlere ilişkin temel istatistikler tablo 2'de özetlenmiştir. İlgili tabloda yer alan bilgileri incelediğimizde Avrupa Birliği üye ülkeleri için 1996-2020 zaman dilimi açısından enflasyon değişkenine ilişkin ortalama 0.72 ve standart sapma 0.92 , yaşlı bağımlı nüfus değişkenine ilişkin ortalama 3.24 ve standart sapması 0.22 , genç bağımlı nüfus değişkenine ilişkin ortalama 3.19 ve standart sapması 0.13 , çalışma çağındaki nüfus değişkenine ilişkin ortalama 4.19 ve standart sapması 0.08 , nüfus artış hızı değişkenine ilişkin ortalama 0.17 ve standart sapması 0.76 , ekonomik büyüme değişkenine ilişkin ortalama 1.06 ve standart sapması 0.71 , işsizlik değişkenine ilişkin ortalama 2.04 ve standart sapması ise 0.47 'dir. Analiz için 1996-2020 olmak üzere 25 yıllık bir zaman dilimi ve yatay kesit olarak ise 27 ülke söz konusudur.

Tablo 3, modelde yer alan değişkenlere ilişkin korelasyon matris sonuçlarını göstermektedir.

Tablo 3. Değişkenler İçin Korelasyon Matrisi

\begin{tabular}{|c|c|c|c|c|c|c|c|}
\hline Korelasyon & LINF & LOLD & LYOUNG & LCCN & LGPOP & LGDP & LUNEMP \\
\hline LINF & 1.00 & & & & & & \\
\hline LOLD & $-0.28^{* * *}$ & 1.00 & & & & & \\
\hline LYOUNG & 0.01 & $-0.40^{* * *}$ & 1.00 & & & & \\
\hline LCCN & $0.16^{* * *}$ & $0.13^{* * *}$ & $-0.24^{* * *}$ & 1.00 & & & \\
\hline
\end{tabular}

\footnotetext{
${ }^{3}$ Analizde yer alan 27 Avrupa Birliği ülkesi: Avusturya, Belçika, Bulgaristan, Hırvatistan, Kıbrıs, Çek Cumhuriyeti, Danimarka, Estonya, Finlandiya, Fransa, Almanya, Yunanistan, Macaristan, İrlanda, İtalya, Letonya, Litvanya, Lüksemburg, Malta, Hollanda, Polonya, Portekiz, Romanya, Slovak Cumhuriyeti, Slovenya, İspanya ve İsveç'tir.
} 
Kaplan, E. A. \& Burgaz, N. (2021). Demografik Göstergelerin Enflasyonla iliş̧kisi: Avrupa Birliği Örneği. Fiscaoeconomia, 5(3), 879-901. Doi: 10.25295/fsecon.945256

Tablo 3. Değişkenler içcin Korelasyon Matrisi

\begin{tabular}{|c|c|c|c|c|c|c|c|}
\hline LGPOP & $-0.23^{* * *}$ & $-0.16^{* * *}$ & $0.21^{* * *}$ & -0.02 & 1.00 & & \\
\hline LGDP & $0.16^{* * *}$ & $-0.22^{* * *}$ & $0.08^{* *}$ & 0.04 & $-0.11^{* * *}$ & 1.00 & \\
\hline LUNEMP & 0.01 & $-0.07^{* *}$ & $-0.12^{* * *}$ & 0.06 & $-0.34^{* * *}$ & 0.02 & 1.00 \\
\hline
\end{tabular}

Not: ${ }^{* * *}$ ve ${ }^{* *}$ sırasıyla \%1 ve \%5 düzeyinde istatistiki anlamlılı̆̆ı ifade etmektedir.

Tablo 3'te yer alan korelasyon katsayıları incelendiğinde, ilgili katsayılar -0.40 ve 0.16 aralığında değişmektedir. Genç bağımlı nüfus, çalışma çağındaki nüfus, ekonomik büyüme ve işsizlik enflasyon ile pozitif ilişkili iken yaşlı bağımlı nüfus ve nüfus artış hızı ile negatif ilişkilidir.

\subsubsection{Yöntem}

Panel veri analizi için uygun yöntemin seçimi, statik panel veri analizi ve panel eş bütünleşme analizi için farklılık göstermektedir. Bu nedenle bu çalışmada yatay kesit bağımlıığı, homojenlik/heterojenlik analizleri sonucu dikkate alındıktan sonra uygun birim kök testinin yapılmasının ardından gerekli analizler yapılmaya çalışılacaktır.

Panel veri analizlerinde yatay kesitler arasındaki bağımlılı̆ı göz ardı eden testler "birinci nesil testler", yatay kesitler arasında bağımlılığa izin veren testler ise "ikinci nesil testler" olarak adlandırımaktadır. Avrupa Birliği ülkelerinin enflasyon, işsizlik ve ekonomik büyüme gibi temel makro ekonomik göstergelerinin gelişmesi için iş birliği mekanizmalarının varlığı, yatay kesitler yani ülkeler arasında bir bağımlılığı göstermektedir. Bu nedenle bu çalışmada öncelikle analizlere dahil edilen ülkeler arasındaki yatay kesit bağımlılığının varlığı yapılan testlerle ispatlanmış ve daha sonra Hsiao (2003) homojenite testleri uygulanmıştır. Yatay kesit bağımlılığını dikkate alan Pesaran CADF birim kök testi de yapılmış ve sonra uygun model seçimi için gerekli testler yapılıp nihai modele karar verilmiştir.

Statik panel veri analizi için ekonometrik modellerin, sabit ve eğim katsayılarının yatay kesit ve zamana göre farklı şekilde tahminleri söz konusudur. Bu çerçevede panel veri regresyonu; klasik (havuzlanmış) regresyon modeli, sabit etkiler modeli ve rassal etkiler modeli olmak üzere tahmin edilmektedir. Sabit etkili model, eğim katsayısının sabit olduğu modellerdir. Tek yönlü ve iki yönlü sabit etkili model olmak üzere farklılık göstermektedir. Hata bileşenleri modeli olarak da bilinen rassal etkili model için birim ve zaman etkileri rassal değişken olarak modelde hata terimi bileşeni olarak dikkate alınmaktadır. Tek yönlü ve iki yönlü rassal etkili model olmak üzere farklılık göstermektedir.

Statik panel veri analizi için bu üç model arasından hangi modelin kullanılacağı spesifikasyon testleri sonucunda belirlenmektedir. Klasik (havuzlanmış) EKK ile sabit etkili model arasında Fischer testi (F testi), klasik (havuzlanmış) EKK ile rassal etkili model arasında BreuschPagan/LM Testi ve Honda Testi, rassal etkili modelin tahmininde ise rassal etkilerin test edilmesi için LM ve Honda testleri kullanılmaktadır. Hausman testi ile de rassal etkili modelin tutarsız olup olmadığına karar verilmektedir.

Ekonometrik varsayımlarından sapmalar hata terimlerinin varyans-kovaryans matrisinde yapısal bozulmalara neden olacağından, otokorelasyon ve değişen varyans sorunlarının var olduğu tespit edilirse tahminlerin gözden geçirilerek yeniden yapılması büyük önem 
Kaplan, E. A. \& Burgaz, N. (2021). Demografik Göstergelerin Enflasyonla iliş̧kisi: Avrupa Birliği Örneği. Fiscaoeconomia, 5(3), 879-901. Doi: 10.25295/fsecon.945256

taşımaktadır. Böylece değişen varyansın varlı̆̆ında tutarlı, otokorelasyon varlığında dirençli standart hatalar üreten yöntemler kullanılması gerekmektedir. Bu nedenle çalışmada bu amaçla literatürde "Beck ve Katz/Parks Tahmincisi" olarak bilinen Panel Düzeltilmiş Standart Hata (Panel Corrected Standard Error-PCSE) yöntemi kullanılarak panel veri modelleri için katsayılar yeniden tahmin edilmiş ve söz konusu sorunların varlığı altında dirençli tahmincilerle yeni tahminler yapılmıştır.

\subsubsection{Ampirik Bulgular}

Tablo 4'te, enflasyon modeline ilişkin modelde yer alan değişkenlere ait yatay kesit bağımlılığı test sonuçları yer almaktadır.

Tablo 4. Yatay Kesit Bağımlılığı Sonuçları

\begin{tabular}{|c|c|c|c|c|}
\hline & Test & İstatis. & d.f. & Olas. \\
\hline \multirow{4}{*}{ LINF } & Breusch-Pagan LM & 1155.88 & 351.00 & 0.00 \\
\hline & Pesaran scaled LM & 30.38 & & 0.00 \\
\hline & $\begin{array}{l}\text { Bias-corrected scaled } \\
\text { LM }\end{array}$ & 29.82 & & 0.00 \\
\hline & Pesaran CD & 26.95 & & 0.00 \\
\hline \multirow{4}{*}{ LOLD } & Breusch-Pagan LM & 7645.64 & 351.00 & 0.00 \\
\hline & Pesaran scaled LM & 275.32 & & 0.00 \\
\hline & $\begin{array}{l}\text { Bias-corrected scaled } \\
\text { LM }\end{array}$ & 274.76 & & 0.00 \\
\hline & Pesaran CD & 77.25 & & 0.00 \\
\hline \multirow{4}{*}{ LYOUNG } & Breusch-Pagan LM & 3921.88 & 351.00 & 0.00 \\
\hline & Pesaran scaled LM & 134.77 & & 0.00 \\
\hline & $\begin{array}{l}\text { Bias-corrected scaled } \\
\text { LM }\end{array}$ & 134.21 & & 0.00 \\
\hline & Pesaran CD & 49.78 & & 0.00 \\
\hline \multirow{4}{*}{ LCCN } & Breusch-Pagan LM & 4933.29 & 351.00 & 0.00 \\
\hline & Pesaran scaled LM & 172.95 & & 0.00 \\
\hline & $\begin{array}{l}\text { Bias-corrected scaled } \\
\text { LM }\end{array}$ & 172.39 & & 0.00 \\
\hline & Pesaran CD & 52.32 & & 0.00 \\
\hline \multirow{4}{*}{ LGPOP } & Breusch-Pagan LM & 1176.90 & 351.00 & 0.00 \\
\hline & Pesaran scaled LM & 31.17 & & 0.00 \\
\hline & $\begin{array}{l}\text { Bias-corrected scaled } \\
\text { LM }\end{array}$ & 30.61 & & 0.00 \\
\hline & Pesaran CD & 0.40 & & 0.69 \\
\hline \multirow{4}{*}{ LGDP } & Breusch-Pagan LM & 780.51 & 351.00 & 0.00 \\
\hline & Pesaran scaled LM & 16.21 & & 0.00 \\
\hline & $\begin{array}{l}\text { Bias-corrected scaled } \\
\text { LM }\end{array}$ & 15.65 & & 0.00 \\
\hline & Pesaran CD & 16.58 & & 0.00 \\
\hline \multirow{2}{*}{ LUNEMP } & Breusch-Pagan LM & 2030.76 & 351.00 & 0.00 \\
\hline & Pesaran scaled LM & 63.40 & & 0.00 \\
\hline
\end{tabular}


Kaplan, E. A. \& Burgaz, N. (2021). Demografik Göstergelerin Enflasyonla illişkisi: Avrupa Birliği Örneği. Fiscaoeconomia, 5(3), 879-901. Doi: 10.25295/fsecon.945256

Tablo 4. Yatay Kesit Bağımlılığı Sonuçları

\begin{tabular}{|l|l|l|l|l|}
\hline & Bias-corrected scaled & & & \\
& LM & 62.84 & & 0.00 \\
\hline & Pesaran CD & 25.44 & & 0.00 \\
\hline
\end{tabular}

Elde edilen sonuçlara göre yatay kesitler arasında bağımlılık olmadığı yönündeki boş hipotez \% 1 düzeyinde reddedilmektedir. Sonuç olarak yatay kesitler yani ülkeler arasında bağımlılık söz konusudur.

Tablo 5'te, enflasyon modeline ait 5 model için Hsiao (2003) homojenite/heterojenite test sonuçları yer almaktadır.

Tablo 5. Homojenite/Heterojenite Test Sonuçları

\begin{tabular}{|l|c|c|}
\hline \multicolumn{3}{|c|}{ Model 1 için sonuçlar } \\
\hline Hypotheses & F-Stat & P-Value \\
\hline H1 & 4.32 & 0.00 \\
\hline H2 & 2.25 & 0.00 \\
\hline H3 & 7.67 & 0.00 \\
\hline \multicolumn{3}{|c|}{ Model 2 için sonuçlar } \\
\hline Hypotheses & F-Stat & P-Value \\
\hline H1 & 3.18 & 0.00 \\
\hline H2 & 2.00 & 0.00 \\
\hline H3 & 6.00 & 0.00 \\
\hline \multicolumn{3}{|c|}{ Model 3 için sonuçlar } \\
\hline Hypotheses & F-Stat & P-Value \\
\hline H1 & 3.18 & 0.00 \\
\hline H2 & 2.00 & 0.00 \\
\hline H3 & 6.00 & 0.00 \\
\hline \multicolumn{3}{|c|}{ Model 4 için sonuçlar } \\
\hline Hypotheses & F-Stat & P-Value \\
\hline H1 & 3.44 & 0.00 \\
\hline H2 & 2.02 & 0.00 \\
\hline H3 & 8.71 & 0.00 \\
\hline \multicolumn{3}{|c|}{ Model 5 için sonuçlar } \\
\hline Hypotheses & F-Stat & P-Value \\
\hline H1 & 3.03 & 0.00 \\
\hline H2 & 1.80 & 0.00 \\
\hline H3 & 8.66 & 0.00 \\
\hline
\end{tabular}

Tablo 5'te yer alan sonuçlar incelendiğinde her bir model için üç hipotez açısından sıfır hipotez reddedilerek alternatif hipotez kabul edilmektedir. Sonuç olarak heterojenite söz konusudur.

Tablo 6'da enflasyon modelinde yer alan değişkenlere ait Pesaran CADF birim kök testi sonuçları yer almaktadır. 
Kaplan, E. A. \& Burgaz, N. (2021). Demografik Göstergelerin Enflasyonla illişkisi: Avrupa Birliği Örneği. Fiscaoeconomia, 5(3), 879-901. Doi: 10.25295/fsecon.945256

Tablo 6. CADF Birim Kök Testi Sonuçları (Düzeyde ve Sabit Terimli)

\begin{tabular}{|l|c|c|c|c|c|c|}
\hline & t-bar & cv10 & cv5 & cv1 & Z[t-bar] & P-value \\
\hline linf & -2.55 & -2.07 & -2.15 & -2.30 & -4.25 & 0.00 \\
\hline lold & -3.08 & -2.07 & -2.15 & -2.30 & -7.03 & 0.00 \\
\hline Iyoung & -2.70 & -2.07 & -2.15 & -2.30 & -5.06 & 0.00 \\
\hline Ipop & -2.19 & -2.07 & -2.15 & -2.30 & -2.34 & 0.01 \\
\hline Iccn & -2.45 & -2.07 & -2.15 & -2.30 & -3.69 & 0.00 \\
\hline Igpop & -2.52 & -2.07 & -2.15 & -2.30 & -4.10 & 0.00 \\
\hline Igdp & -2.30 & -2.07 & -2.15 & -2.30 & -2.93 & 0.00 \\
\hline lunemp & -3.15 & -2.07 & -2.15 & -2.30 & -4.67 & 0.00 \\
\hline
\end{tabular}

Tablo 6'da yer alan sonuçlar incelendiğinde tüm değişkenler için sıfır hipotez \%1 düzeyinde reddedilerek alternatif hipotez kabul edilir. Sonuç olarak tüm değişkenler için durağanlık söz konusudur.

Birim kök testi sonucunda serilerin durağan olması eş bütünleşme ilişkisinin araştırılmasına izin vermemektedir. Bu çerçevede statik panel veri analizi metodolojisi dikkate alınarak model tahmin sonuçları incelenmeye çalışılacaktır.

Tablo 7'te, enflasyon modeline ilişkin statik panel veri analizi çerçevesinde tahmin sonuçları yer almaktadır. Örneklem grubunda yer alan AB üyesi 27 ülke analize dahil edildiği için sabit etkiler modeli dikkate alınmıştır.

Tablo 7. Statik Panel Veri Analiz Sonuçları (Bağımlı Değişken: LINF)

\begin{tabular}{|c|c|c|c|c|c|}
\hline & 1.Model & 2.Model & 3.Model & 4.Model & 5.Model \\
\hline \multicolumn{6}{|l|}{ Değişkenler } \\
\hline C & $1.33^{* * *}$ & $1.11^{* * *}$ & 9.18 & 2.16 & $15.62^{*}$ \\
\hline LOLD & & & & & $-1.78^{* * *}$ \\
\hline LYOUNG & & & & $0.89^{*}$ & 0.73 \\
\hline LCCN & & & -1.92 & -0.92 & -2.61 \\
\hline LGPOP & & $0.18^{* * *}$ & $0.19^{* * *}$ & $0.19^{* * *}$ & $0.16^{* *}$ \\
\hline LGDP & -0.06 & -0.06 & -0.06 & -0.04 & -0.03 \\
\hline LUNEMP & $-0.25^{* *}$ & -0.16 & -0.17 & -0.16 & $-0.26^{* *}$ \\
\hline $\bar{R}^{2}$ & 0.44 & 0.45 & 0.45 & 0.45 & 0.46 \\
\hline$F_{\text {group_fixed }}$ & $\begin{array}{l}11.31 \\
(0.00)\end{array}$ & $\begin{array}{c}9.52 \\
(0.00)\end{array}$ & $\begin{array}{c}9.11 \\
(0.00)\end{array}$ & $\begin{array}{c}9.14 \\
(0.00)\end{array}$ & $\begin{array}{c}8.12 \\
(0.00)\end{array}$ \\
\hline $\mathrm{F}_{\text {time_fixed }}$ & $\begin{array}{l}11.44 \\
(0.00)\end{array}$ & $\begin{array}{l}11.72 \\
(0.00)\end{array}$ & $\begin{array}{l}10.33 \\
(0.00)\end{array}$ & $\begin{array}{c}7.80 \\
(0.00) \\
\end{array}$ & $\begin{array}{c}4.08 \\
(0.00) \\
\end{array}$ \\
\hline$F_{\text {twoway_fixed }}$ & $\begin{array}{l}11.03 \\
(0.00)\end{array}$ & $\begin{array}{c}9.99 \\
(0.00)\end{array}$ & $\begin{array}{c}9.49 \\
(0.00)\end{array}$ & $\begin{array}{c}9.42 \\
(0.00)\end{array}$ & $\begin{array}{c}6.98 \\
(0.00)\end{array}$ \\
\hline $\mathrm{LMh}_{\text {fixed }}$ & $\begin{array}{l}99.70 \\
(0.00)\end{array}$ & $\begin{array}{l}97.45 \\
(0.00)\end{array}$ & $\begin{array}{l}111.21 \\
(0.00)\end{array}$ & $\begin{array}{l}92.65 \\
(0.00) \\
\end{array}$ & $\begin{array}{l}80.82 \\
(0.00) \\
\end{array}$ \\
\hline $\mathrm{LM}_{\text {stat }}$ & $\begin{array}{l}66.46 \\
(0.00)\end{array}$ & $\begin{array}{l}66.49 \\
(0.00)\end{array}$ & $\begin{array}{l}50.76 \\
(0.00)\end{array}$ & $\begin{array}{l}37.24 \\
(0.00)\end{array}$ & $\begin{array}{l}22.91 \\
(0.00)\end{array}$ \\
\hline DW & 1.21 & 1.21 & 1.27 & 1.37 & 1.51 \\
\hline
\end{tabular}


Kaplan, E. A. \& Burgaz, N. (2021). Demografik Göstergelerin Enflasyonla Iliş̧kisi: Avrupa Birliği Örneği. Fiscaoeconomia, 5(3), 879-901. Doi: 10.25295/fsecon.945256

Tablo 7. Statik Panel Veri Analiz Sonuçları (Bağımlı Değişken: LINF)

\begin{tabular}{|l|c|c|c|c|}
\hline$(0.00)$ & $(0.00)$ & $(0.00)$ & $(0.00)$ & $(0.00)$
\end{tabular}

Not: ${ }^{* * *},{ }^{* *},{ }^{*}$ sırasıyla, \%1, \%5 ve \%10 düzeyinde istatistiki anlamlılığı ifade etmektedir. Spesifikasyon test sonuçlarına göre 1.model için iki yönlü sabit etkiler modeli, 2.model için iki yönlü sabit etkiler modeli, 3.model için iki yönlü sabit etkiler modeli, 4.model için iki yönlü sabit etkiler modeli ve 5.model için iki yönlü sabit etkiler modeli en uygun model olarak belirlenmiştir. LMhfixed sabit etkiler modeli için değişen varyans test istatistiğini, $\mathrm{LM}_{\text {stat }}$ ve DW (Durbin Watson) sabit etkiler modeli için otokorelasyon test istatistiğini göstermektedir. Tüm modellerin sonuçları için değişen varyans ve otokorelasyon sorununu dikkate alan dirençli tahminciler kullanılmıştır.

Tablo 7'de yer alan 1.model için tahmin sonuçları incelendiğinde ekonomik büyümede meydana gelecek \%1'lik bir artış enflasyonu \%0.06, işsizlikte meydana gelecek \%1'lik bir artış enflasyonu \%0.25 azaltmaktadır. Bu modelde işsizlik katsayısı istatistiksel olarak anlamlıdır.

Tablo 7'de yer alan 2.model için tahmin sonuçları incelendiğinde nüfus artış hızında meydana gelecek \%1'lik bir artış enflasyonu \%0.18 arttırırken, ekonomik büyümede meydana gelecek \%1'lik bir artış enflasyonu \%0.06, işsizlikte meydana gelecek \%1'lik bir artış enflasyonu \%0.16 azaltmaktadır. Bu modelde nüfus artış hızına ilişkin katsayı istatistiksel olarak anlamlıdır.

Tablo 7'de yer alan 3.model için tahmin sonuçları incelendiğinde çalışma çağındaki nüfusta meydana gelecek \%1'lik bir artış enflasyonu \%1.92, ekonomik büyümede meydana gelecek $\% 1^{\prime}$ lik bir artış ise enflasyonu \%0.06, işsizlikte meydana gelecek \%1'lik bir artış enflasyonu \%0.17 azaltırken, nüfus artış hızında meydana gelecek \%1'lik bir artış enflasyonu \%0.19 arttırmaktadır. Bu modelde nüfus artış hızına ilişkin katsayı istatistiksel olarak anlamlıdır.

Tablo 7'de yer alan 4.model için tahmin sonuçları incelendiğinde genç bağımlı nüfusta meydana gelecek \%1'lik bir artış enflasyonu \%0.89, nüfus artış hızında meydana gelecek \%1'lik bir artış enflasyonu \%0.19 arttırırken, çalışma çağındaki nüfusta meydana gelecek \%1'lik bir artış enflasyonu \%0.92, ekonomik büyümede meydana gelecek \%1'lik bir artış enflasyonu $\% 0.04$, işsizlikte meydana gelecek \%1'lik bir artış ise enflasyonu \%0.16 azaltmaktadır. Bu modelde genç bağımlı nüfusa ilişkin katsayı ve nüfus artış hızına ilişkin katsayı istatistiksel olarak anlamlıdır.

Tablo 7'de yer alan 5.model için tahmin sonuçları incelendiğinde yaşlı bağımlı nüfusta meydana gelecek \%1'lik bir artış enflasyonu \%1.78, çalışma çağındaki nüfusta meydana gelecek \%1'lik bir artış enflasyonu \%2.61, ekonomik büyümede meydana gelecek \%1'lik bir artış enflasyonu \%0.03, işsizlikte meydana gelecek \%1'lik bir artış enflasyonu \%0.26 azaltırken, genç bağımlı nüfusta meydana gelecek \%1'lik bir artış enflasyonu \%0.73, nüfus artış hızında meydana gelecek \%1'lik bir artış enflasyonu \%0.16 arttırmaktadır. Bu modelde yaşlı bağımlı nüfus, nüfus artış hızı ve işsizlik değişkenlerine ilişkin katsayılar istatistiksel olarak anlamlıdır.

\section{Sonuç}

Yapılan çalışma enflasyonu farklı bir açıdan ele alarak sosyal çerçevede incelemiştir. Enflasyonun ekonomik perspektiften birçok yönüyle incelenmesine rağmen demografik açısından incelenmesi oldukça sınırlıdır. $A B$ ülkelerindeki düşük enflasyonun nedenleri ekonomik çerçevede incelenmiş ancak demografik göstergelerin enflasyon üzerindeki etkisine dair çalışma yapılmaması bu çalışmanın özgünlüğünü ortaya koymaktadır. $A B$ ülkelerinin 
Kaplan, E. A. \& Burgaz, N. (2021). Demografik Göstergelerin Enflasyonla illişkisi: Avrupa Birliği Örneği. Fiscaoeconomia, 5(3), 879-901. Doi: 10.25295/fsecon.945256

seçilmesinin nedeni doğum oranlarının azalması ve yaşlanan nüfusun birlik ekonomisi üzerindeki etkisinin tedirgin etmesi sebebiyle seçilmiştir.

Bu çalışmada 1996-2020 zaman dilimi AB üyesi ülkeler için demografik göstergelerin makroekonomik unsurlar ve enflasyonla ilişkisi incelenmiştir. Analiz sonucunda en dikkat çekici olan husus hem yaşlı bağımlı nüfusun hem de çalışma çağındaki nüfusun enflasyon üzerinde negatif etkisi olduğudur. Yaşlı bağımlı nüfusun düzenli tüketim seviyelerini sürdürmek için çalışma hayatları boyunca biriktirdikleri birikimleri kademeli olarak kullandıklarını öngörüldüğünde yaşlı nüfusun daha düşük tasarruf oranlarına sahiptir. Yaşlı toplumlar daha fazla toplam tüketim ve daha düşük toplam tasarruf gösterme eğiliminde olması sebebiyle enflasyon üzerinde pozitif etkisi olması beklenilmektedir (Borrallo ve ark., 2012:12). Ancak analiz sonucuna göre beklentilerin aksine ilişki bulunulmuştur. Japonya'da da son yirmi yılda eşzamanlı olarak hem nüfusunun yaşlanması hem de deflasyon görülmektedir. Bu durum Japonya'da bu yaş grubunun sosyal güvenlik sistemine yük olmaları sebebiyle daha ağır vergilendirilmesi ve gelirleri düşen yaşlı bağımlı nüfusun tüketim eğilimlerinin daha düşük olmasından kaynaklanmaktadır. $A B$ ülkelerinde ise hem bu yaş grubunun vergilendirilmesinin birbirinden farklı olması hem de yaşlı bakım ve sağlık hizmetlerinin pahalı olup olmamasına göre tüketim eğilimleri değişiklik gösterdiğinden genel bir kanıya varmak oldukça zor olsa da yaşlı bağımlı nüfus artıkça enflasyon azalmaktadır.

Çalışma çağındaki nüfusun ise gelirlerinin yüksek olduğu bu dönemde gelecek kaygısı ile tasarruf yapma eğilimlerinin yüksek olması nedeniyle enflasyon düşürücü etkisi olduğu söylenebilir. $A B$ ülkelerinde çalışma çağındaki nüfusun toplam nüfus içindeki payı yüksek olduğu düşünüldüğünde enflasyonu düşürücü etkisinin daha fazla olması analiz sonucuyla uyumludur.

Nüfus artış hızının artması durumunda da enflasyon artmaktadır. Daha yüksek nüfus daha fazla tüketim anlamına gelmekte ve toplam talebin artması ile enflasyonu artmaktadır. Genç bağımlı nüfus olarak adlandırılan 0-14 yaş tüketim eğilimlerinin yüksek olması nedeniyle enflasyonu artırmaktadır.

Özet olarak demografik göstergelerin enflasyon etkisine bakıldığında doğum oranlarının azaldığı $A B$ ülkelerinde genç bağımlı nüfus oranının azalması enflasyonu artırıcı etkisinin daha az olması, yaşlı bağımlı nüfusun ve çalışma çağındaki nüfusun toplam nüfus içindeki payının yüksek olduğu düşünüldüğünde enflasyon üzerindeki düşürücü etkisinin daha fazla olması analiz sonuçlarıyla uyumlu olduğu söylenebilir.

Analizde makroekonomik değişkenlerin enflasyon üzerinde etkisine kısaca değinildiğinde işsizlik artığında enflasyon düşmektedir. İktisat literatüründe bu ters ilişki Phillips eğrisi ile açıklanabilmekte ve analiz sonuçlarıyla uyumludur. İşsizlik oranı artığında toplam talep azalmakta ve enflasyon düşmektedir. Eurostat verilerine göre Avrupa Birliği'nde işsizlik oranları ortalama 8,5 düzeyindedir. Yüksek işsizlik sebebiyle toplam talebin düşmesi enflasyonu azaltıcı etkiyi açıklamaktadır.

Sonuç olarak $A B$ ülkelerinde yaşanan değişimin uzun vadede enflasyon etkisi dikkat çekicidir. Nüfus projeksiyon göstergelerine bakıldığında birliğin doğum oranlarının daha da azalmasına ve nüfusun daha da azalacağı tahmin edilmesi ile nüfus artış hızı, çalışma çağındaki nüfus ve 
Kaplan, E. A. \& Burgaz, N. (2021). Demografik Göstergelerin Enflasyonla İlişkisi: Avrupa Birliği Örneği. Fiscaoeconomia, 5(3), 879-901. Doi: 10.25295/fsecon.945256

bağımlı nüfusun daha da düşeceği beklentisi ekonomik gerekçeler dışında demografik etkiler nedeniyle enflasyonun daha düşeceğini söylemek mümkün olabilmektedir.

\section{Kaynakça}

Akçay, E. Y., Argun, Ç., Akman, E. (2011). AB’nin Tarihsel Gelişimi ve Ortak Dış ve Güvenlik Politikası, 3(4), 121-122.

Akyıldız, N. A. (2020). Evaluation of Elderly Population Policies in Development Plans in the Context of Social Sustainability, International Journal of Recent Advances in Multidisciplinary Research, 7(3), 5653-5661.

Andrews, D., Oberoi, J., Wirjanto, T. Zhou, C. (2018). Demography and Inflation: An International Study. North American Actuarial Journal, 22(2), 210-222,

Ataç, B. (2009). Maliye Politikası, Ankara: Turhan Kitabevi, Gözden Geçirilmiş Sekizinci Baskı, 162-163.

Bavel, J. V., \& Reher, D.S. (2013). The Baby Boom and Its Causes: What We Need to Know, Population and Development Review, 39(2), 257.

Birinci, Y. (1989). Enflasyon, Para Politikası ve Stratejileri, Istanbul Üniversitesi Iktisat Fakültesi Mecmuası, 47(1-40), 20

Bobeica, E., Lis, E., Nickel, C., Sun, Y. (2017). Demographics and Inflation, ECB Working Paper, No. 2006, 1-24.

Borrallo,F., Parraga-Rodriguez, S., Perez, J. J. (2012). Taxatıon Challenges Of Populatıon Ageıng: Comparative Evidence From The European Unıon, The United States And Japan, Banco de Espana, Documentos Ocasionales No:2102, 12.

Broniatowska, P. (2019). Population Ageing and Inflation, Population Ageing, 12, 179-193.

Bulir, A. \& Hurnik, J. (2006). The Maastricht Inflation Criterion: How Unpleasant Is Purgatory?, International Monetary Fund, Working Paper, 06/154, 3-4.

Dabrowski, M. (2019). The Economic and Monetary Union: Past, Present and Future, European Parliament, 7. https://www.europarl.europa.eu/cmsdata/159703/CASE final\%20publication.pdf

Dayıoğlu, M. R. (2018). Mali Sosyoloji ve Vergi Uyumu, Ankara: Gazi Kitabevi.

Duarte, M. (2003). The Euro and Inflation Divergence in Europe, Federal Reserve Bank of Richmond Economic Quarterly, 89(3), 54-55.

Dünya Bankası. Databank. Erişim Adresi: https://databank.worldbank.org/source/worlddevelopment-indicators 
Kaplan, E. A. \& Burgaz, N. (2021). Demografik Göstergelerin Enflasyonla illişkisi: Avrupa Birliği Örneği. Fiscaoeconomia, 5(3), 879-901. Doi: 10.25295/fsecon.945256

European Commission. (2012). Ageing Europre, Eurostat, 8. Erişim adresi: https://ec.europa.eu/eurostat/documents/3217494/10166544/KS-0219\%E2\%80\%91681-EN-N.pdf/c701972f-6b4e-b432-57d2-91898ca94893

DeNederlandscheBank. (2016). Inflation in The Euro Area, Occasional Studies, 14(3), 29.

Eraslan, M. T. (2011). Ekonomik ve Parasal Birliğin Teknik Yapısı ve Türkiye'nin Sisteme Dahil Olması, DPT Uzmanlık Tezi, Yayın No:2823, 68-69.

European Central Bank. (2014). ECB Monthly Bulletin, 5, 68, https://www.ecb.europa.eu/pub/pdf/other/mb201406_focus05.en.pdf.

European Parliamentary. (2021). Demographic Outlook for the European Union. European Parliamentary Research Service, 11-12. Erişim adresi: https://www.europarl.europa.eu/RegData/etudes/STUD/2021/690528/EPRS_STU(20 21)690528_EN.pdf.

Eurostat. (2020). Population Structure and Ageing, 8. Erişim adres: https://ec.europa.eu/eurostat/statistics-explained/pdfscache/1271.pdf

Goldstein, J. R., Lee, R. D. (2020). Demographic perspectives on mortality of Covid-19 and other epidemics. NBER, Working Paper 27043, 2.

Han, G. (2019). Demographic Changes and Inflation Dynamics, Hong Kong Institute For Monetary Research, HKIMR Working Paper No:02/2019, 1-25.

Hauser, P. M. (1959). Demographic Indicator of Economic Development, Economic Development and Cultural Change, 7(2), 100-106.

Illgili, Ö., Gökçe Kutsal, Y. (2020). Impact of Covid-19 Among The Elderly Population, Turkısh Journal of Geriatrics, 23(4), 419.

Günaydın, D. (2018). Türkiye'nin Demografik Dönüşümü Çerçevesinde Yaşlanma Sorunu, Yaşlı Sorunları Araştırma Dergisi, 11(1), 5.

Jaffrı, A. A., Farrooq, F., Munır, F. (2016). Impact of Demographic Changes On Inflation In Pakıstan, Pakistan Economic and Social Review, 54(1), pp.1-14.

Jozwiak, J. \& Kotowska, I. E. (2008). Decreasing Birth Rates in Europe: Reasons and Remedies, European View, 7, 231.

Juselius, M. \& Takats, E. (2015). Can demography affect inflation and monetary policy?", Bank For International Settlements, no. 485, 1-35, 2015. [Online] Available:https://www.bis.org/publ/work485.pdf

Kalkınma Bakanlığı. (2018). Enflasyonla Mücadele Özel İhtisas Komisyonu Raporu, Ankara: Kalkınma Bakanlığı, 4-5.

Kleiman, E. (1967). A Standardized Dependency Ratio, Demography, 4(2), 876-877. 
Kaplan, E. A. \& Burgaz, N. (2021). Demografik Göstergelerin Enflasyonla İlişkisi: Avrupa Birliği Örneği. Fiscaoeconomia, 5(3), 879-901. Doi: 10.25295/fsecon.945256

Karatağ, H. \& Akyıldız, N. A. (2019). Avrupa'nın Demografik Dönüşümünde Uzun Dönem Yaşlı Bakımının Sürdürülebilirliğinin Değerlendirilmesi, Sosyal Politika Çalışmaları Dergisi, 19(44), 571-595.

Kocağ Karapınar, E. \& Bakan, S. (2013). Avrupa Birliği'ne Üyeliğin Maastricht Kriterleri Çerçevesinde Ekonomik İstikrar Açısından Değerlendirilmesi, International Journal of Social Science, 6(1), 943.

Liu, Y. \& Westelius, N. (2016). The Impact of Demographics on Productivity and Inflation in Japan, IMF Working Paper, WP/16/237, 1-17.

Manga, M. \& Cengiz, O. (2020). Türkiye'de Nüfus Yapısı ve Enflasyon Ilişkisi, İstanbul Ticaret Üniversitesi Sosyal Bilimler Dergisi, Prof. Dr. Sabri Orman Özel Sayısı, 335-352.

Nişancı, M., Yurttançıkmaz, Z. Ç., Türkmen, A., Emsen, Ö. S. (2014). Ekonomik Performans Kriteri Olarak Maatricht Kriterlerine Yakınsama: Geçiş Ekonomileri Üzerine Uygulama, International Conference On Eurasian Economies 2014, 1-2. https://www.avekon.org/papers/921.pdf

OECD, Working Age Population, OECD Library, https://www.oecd-ilibrary.org/social-issuesmigration-health/working-age-population/indicator/english d339918b-

en\#: : text=The\%20working\%20age\%20population\%20is,those\%20aged\%2015\%20to \%2064.

Papaioannou, G. (2004). The European Union in the 90's. Fiscal Conditions and Concerns, European Research Studies, VII(3-4), 9.

Population Europe. (2020). Demography and The Coranavirus Pandemic, Erişim adresi: https://population-europe.eu/policy-brief/demography-and-coronavirus-pandemic.

Prskawetz, A., Fent, T., Barthel, W. (2007). The Relationship Between Demographic Change and Economic Growth in The EU, Institut für Demographie Vienna Institute of, 5, Erişim adresi:

https://www.oeaw.ac.at/fileadmin/subsites/Institute/VID/PDF/Publications/Forschu ngsberichte/FB32.pdf

TCMB. (2013). Enflasyon ve Fiyat İstikrarı, Ankara: TCMB, 6-8.

United Nations. (1953). The Determinants and Consequences of Population Trends, Population Studies No:17, 47.

https://www.un.org/development/desa/pd/sites/www.un.org.development.desa.pd /files/files/documents/2020/Jan/un 1953 determinantsandconsequencesofpopulati ontrends $0 . p d f$

United Nations. (2011). Population Age Structure, United Nations Department of Economic and

Social

Affairs, 
Kaplan, E. A. \& Burgaz, N. (2021). Demografik Göstergelerin Enflasyonla İlişkisi: Avrupa Birliği Örneği. Fiscaoeconomia, 5(3), 879-901. Doi: 10.25295/fsecon.945256

https://www.un.org/en/development/desa/population/publications/pdf/policy/WPP 2011/Chapters/j_Ch_3_Population_Age_Structure.pdf.

Vlandas, T. (2016). The Impact of The Elderly on Inflation Rates In Developed Countries, London School Of Economics, Paper Series No. 107/2016, 1-45.

Yoon, J. W., Kim, J., Lee, J. (2014). Impact of Demographic Changes on Inflation and The Macroeconomy", International Monetary Fund, no, 14/210, pp.1-23, https://www.imf.org/external/pubs/ft/wp/2014/wp14210.pdf

Etik Beyanı: Bu çalışmanın tüm hazırlanma süreçlerinde etik kurallara uyulduğunu yazarlar beyan eder. Aksi bir durumun tespiti halinde Fiscaoeconomia Dergisinin hiçbir sorumluluğu olmayıp, tüm sorumluluk çalışmanın yazarlarına aittir.

Yazar Katkıları: Neslihan BURGAZ, çalışmada Giriş, Sonuç, Kuramsal Çerçeve ve Ampirik Literatür bölümlerinde ve veri toplama aşamalarında katkı sağlamıştır. Emin Ahmet KAPLAN, çalışmada Giriş, Veri Seti, Ekonometrik Metodoloji ve Bulgular bölümlerinde ve veri toplama ile analiz aşamalarında katkı sağlamıştır. 1. yazarın katkı oranı: \%50, 2. yazarın katkı oranı: \%50.

Çıkar Beyanı: Yazarlar arasında çıkar çatışması yoktur.

Ethics Statement: The authors declare that ethical rules are followed in all preparation processes of this study. In case of detection of a contrary situation, Fiscaoeconomia has no responsibility and all responsibility belongs to the authors of the study.

Author Contributions: Neslihan BURGAZ contributed to the study in Introduction, Conclusion, Theoretical Framework and Empirical Literature sections and data collection stages. Emin Ahmet KAPLAN contributed to the study in the Introduction, Data Set, Econometric Methodology and Results sections, in the data collection and analysis stages. 1st author's contribution rate: $50 \%$, 2nd author's contribution rate: $50 \%$.

Conflict of Interest: There is no conflict of interest between the authors. 
Kaplan, E. A. \& Burgaz, N. (2021). Demografik Göstergelerin Enflasyonla iliş̧kisi: Avrupa Birliği Örneği. Fiscaoeconomia, 5(3), 879-901. Doi: 10.25295/fsecon.945256

The Relationship Between Demographic Indicators and Inflation: The Example of the European Union

\section{Emin Ahmet KAPLAN, Neslihan BURGAZ}

\section{Extended Abstract}

Demographic indicators are listed as birth rates, death rates, population growth rate, working age population, young and old dependent population. Due to the increase and decrease in birth and death rates, there is an increase and decrease in the population growth rate, the working age population, the young and old dependent population. The working age population is defined as the population between the ages of 15-64. The higher the working age population, the higher the potential to bear the burden of the young and old dependent population. The young dependent population includes the population in the 0-14 age range. The elderly dependent population includes the population over the age of 64 . In the European Union countries, the population decreased rapidly during World War II, but with the increase in marriage rates after the war, birth rates increased and a baby boom was experienced. This process continued from 1940 to 1960 and the number of children per woman increased rapidly due to the rapid increase in birth rates. After 1960, the process reversed and the number of children per woman started to decrease. While the number of live births per woman in the EU countries was 2.6 in 1960, this number decreased to less than two children after 1980. While the number of children born alive per woman was 1.77 in 1990, it fell below 1.5 in 1996, and remained stable in 1.54 children after 2006. After 1980, the number of children per woman fell below the population renewal level. The main reason for the decline in birth rates has been the changing role of women in social and economic life. As a natural consequence of the decrease in the number of children per woman, the population growth rate, the young dependent population and the population of working age have decreased. In 1960, 40\% of the EU population consisted of a young dependent population, while in 1980 this figure fell to $30 \%$, in 2002 to $25 \%$, and in 2019 this figure decreased to about $23 \%$. While the working age population was $64 \%$ in 1960 , it increased to $68 \%$ in the early 1990 s, and after 2010, this rate decreased to $66 \%$ in 2019.

While the elderly dependent population in EU countries was $11 \%$ in the 1960 s, this rate reached $22 \%$ in 1995 and $31 \%$ in 2020. After 1960, mortality rates decreased. Thanks to positive developments in medicine, technology and health sector, death rates have decreased. Due to the decrease in death rates, the elderly dependent population has increased. According to population projection estimates, it is estimated that the change in demographic indicators in EU countries will continue until 2100. Between the years 2030-2100, it is predicted that the share of the elderly in the total population will increase even more, and the young dependent population and the working age population will continue to decrease. The decrease in birth and death rates in European Union countries and the decrease in these rates affect the ratios of the working age population, young and elderly dependent population. Changes in demographic indicator rates have economic effects. Studies on the economy of demographic indicators have generally been analyzed in terms of macro, but studies on the effect of demographic indicators on inflation have been limited. Due to the fact that these indicators 
Kaplan, E. A. \& Burgaz, N. (2021). Demografik Göstergelerin Enflasyonla illişkisi: Avrupa Birliği Örneği. Fiscaoeconomia, 5(3), 879-901. Doi: 10.25295/fsecon.945256

are social factors and their long-term effects occur, studies in the field of economy have remained at a limited level.

Studies of demographic indicators on inflation have often focused on explaining the years of stagnation in Japan. As a result of the analyzes made in countries other than Japan, there are studies showing that the population growth rate and the elderly dependent population increase inflation in terms of demographic indicators, while the young dependent population and the working age population reduce inflation. There are no studies on the effect of demographic indicators in European Union countries on inflation. In this study, the inflation process of the European Union Countries has been tried to be analyzed in terms of demographic indicators. European Union countries have to comply with some common criteria in economic terms. The European integration process started with the aim of ensuring peace after the 2nd World War and this process was taken further over the years and became a unity. European Union countries have switched to a common currency in order to consolidate economic cooperation and ensure financial stability. Some economic criteria have been introduced in order to adopt a common currency. One of these criteria is the regulation on inflation. According to the regulation on inflation, the average inflation rate of the three EU member countries with the most successful performance does not exceed 1.5 points. Member states or countries wishing to become members must meet these criteria. The inflation criterion has been effective on all EU countries. Member countries have implemented policies to provide inflation criteria, and countries with high inflation have managed to reduce inflation. Due to the weak domestic demand and low energy prices, inflation remained at a low level. At the same time, inflation remained low, thanks to the stability of the euro and being the most important currency after the dollar. Inflation has decreased due to the decrease in domestic demand, especially with the effect of the 2008 Global Crisis. In the postcrisis period, inflation remained low and even negative. In this study, a panel data analysis covering the period 1996-2020 was conducted to test the effects of the changes in the demographic indicators of the European Union countries on inflation. Inflation was used as the independent variable. Population growth rate, working age population, young dependent population, elderly dependent population growth and unemployment data were used as dependent variables. Five models were used in the study. When the estimation results for the 1 st model are examined, it has been determined that a $1 \%$ increase in economic growth will reduce inflation by $0.06 \%$, and a $1 \%$ increase in unemployment will reduce inflation by $0.25 \%$. In this model, the unemployment coefficient is statistically significant. When the estimation results for the second model are examined, a 1\% increase in population growth rate will increase inflation by $0.18 \%$, while a $1 \%$ increase in economic growth will decrease inflation by $0.06 \%$, and a $1 \%$ increase in unemployment will decrease inflation by $0.16 \%$ has been determined. In this model, the coefficient of population growth rate is statistically significant. When the estimation results for the 3rd model are examined, a 1\% increase in the working age population will reduce inflation by $1.92 \%$, a $1 \%$ increase in economic growth will reduce inflation by $0.06 \%$, and a $1 \%$ increase in unemployment will decrease inflation by $0.17 \%$. A $1 \%$ increase in the population growth rate will increase inflation by $0.19 \%$. In this model, the coefficient of population growth rate is statistically significant. When the estimation results for the 4th model are examined, a 1\% increase in the young dependent population will increase inflation by $0.89 \%$, a $1 \%$ increase in the population growth rate will increase inflation 
Kaplan, E. A. \& Burgaz, N. (2021). Demografik Göstergelerin Enflasyonla İlişkisi: Avrupa Birliği Örneği. Fiscaoeconomia, 5(3), 879-901. Doi: 10.25295/fsecon.945256

by $0.19 \%$, while a $1 \%$ increase in the working age population will increase inflation $0.92 \%$, a $1 \%$ increase in economic growth reduces inflation by $0.04 \%$, and a $1 \%$ increase in unemployment reduces inflation by $0.16 \%$. In this model, the coefficient for the young dependent population and the coefficient for the population growth rate are statistically significant. When the estimation results for the 5 th model are examined, a $1 \%$ increase in inflation in the elderly dependent population will be $1.78 \%$, a $1 \%$ increase in inflation in the working age population will be $2.61 \%$, a $1 \%$ increase in economic growth will increase in inflation $0.03 \%$ While a $1 \%$ increase in unemployment reduces inflation by $0.26 \%$, a $1 \%$ increase in youth dependent population increases inflation by $0.73 \%$, a $1 \%$ increase in population growth rate increases inflation by $0.16 \%$. In this model, the coefficients for the elderly dependent population, population growth rate and unemployment variables are statistically significant. In summary, according to the results of the analysis, it has been determined that the elderly dependent population, economic growth, unemployment and the working age population reduce inflation, while the young dependent population and the increase in the population growth rate increase inflation. 